\title{
PENGARUH JENIS SIRIH DAN VARIASI KONSENTRASI EKSTRAK TERHADAP PERTUMBUHAN JAMUR Candida albicans
}

\author{
Diana Etika Rahma Utami ${ }^{1}$, Lutvia Krismayanti ${ }^{2}$, dan Yahdi $^{3}$ \\ 1 Jurusan Tadris IPA Biologi FITK IAIN Mataram \\ ${ }^{2}$ Dosen Jurusan Tadris IPA Biologi FITK IAIN Mataram \\ ${ }^{3}$ Dosen Jurusan Tadris IPA Biologi FITK IAIN Mataram
}

\begin{abstract}
Abstrak
Penelitian ini bertujuan untuk mengetahui pengaruh Ekstrak jenis daun sirih dan variasi konsentrasi terhadap pertumbuhan jamur Candida albicans. Jenis penelitian yang digunakan adalah eksperimen dengan rancangan acak lengkap factorial yang terdiri dari dua faktor, lima perlakuan dan empat kali ulangan. Jenis daun sirih yang digunakan adalah daun sirih hijau (Piper bettle L ) dan daun sirih merah ( Piper crocatum Rutz \& Pav), dan variasi konsentrasi yang digunakan mulai dari 20\%, 40\%, 60\%, 80\%, dan 100\%. Penelitian dilakukan dengan menggunakan metode agar yaitu teknik sumuran, pengukuran diameter zona hambat dengan menggunakan penggaris sebagai indikator penghambatan pertumbuhan jamur. Data penelitian dianalisis dengan menggunakan ANOVA (Analisis Of Variance) dua arah ( Two way anova) dengan bantuan SPSS Versi 16. Hasil analisis menunjukkan $F_{\text {hitung A }}(706,70) \geq F_{\text {tabel }}(4,17)$ yang artinya ada pengaruh ekstrak jenis daun sirih terhadap jamur Candida albicans. Dan $\mathrm{F}$ hitung $\mathrm{B}$ $(6,54) \geq F_{\text {tabel }}(2,68)$ yang artinya ada pengaruh variasi konsnetrasi terhadap pertumbuhan jamur Candida albicans.

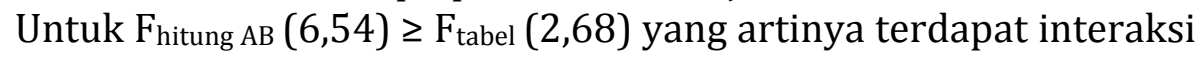
antar faktor A dan faktor B. Uji lanjut dengan uji BNJ 5\% untuk faktor A sebesar 3,60, faktor B sebesar 2,26. Memperlihatkan hasil bahwa jenis daun sirih dan variasi konsentrasi berpengaruh terhadap pertumbuhan jamur Candida albicans.
\end{abstract}

Kata Kunci: Pengaruh Jenis Sirih, Variasi Konsentrasi, Candida albicans 


\section{PENDAHULUAN}

Penggunaan tumbuhan sebagai obat tradisional sudah diketahui oleh masyarakat Indonesia sejak dulu. Biasanya, pemanfaatan tumbuhan obat tersebut digunakan sebagai salah satu upaya untuk menghadapi masalah kesehatan atau penyakit yang menyerang. Galuh (2010) Tumbuhan merupakan salah satu kekayaan sumber daya alam hayati di Indonesia. Tumbuhan memiliki kandungan zat kimia aktif yang sangat berlimpah. Tumbuhan tersebut sangat berpotensi menjadi bahan baku obat tradisional. Salah satu jenis tumbuhan yang digunakan sebagai pengobatan tradisional adalah sirih. Tanaman sirih ini berbagai macam varietas warna daun diantaranya sirih hijau, sirih merah, sirih kuning, siirh hutan, sirih perak dan sirih hitam. Dari sinilah kita bisa melihat kekuasaan Allah SWT sesuai dengan firman-Nya dal AL-Quran surat Ali Imran ayat 191 yang artinya sebagai berikut:

" (yaitu) orang-orang yang mengingat Allah sambil berdiri atau duduk atau dalam keadaan berbaring dan mereka memikirkan tentang penciptaan langit dan bumi (seraya berkata): "Ya Tuhan Kami, tiadalah engkau menciptakan ini dengan sia-sia, Maha suci engkau, Maka peliharalah kami dari siksa neraka.

Galuh (2010) Daun sirih hijau ( Piper betle L) merupakan salah satu tanaman obat yang banyak tumbuh di Indonesia. Masyarakat Indonesia sendiri telah menggunakan daun sirih hijau dalam pengobatan tradisional untuk menguatkan gigi, dsbnya. Daun sirih (Piper betle L) memiliki daya antibakteri terhadap beberapa bakteri pathogen.

Pratiwi (2012) Minyak esensial daun sirih mengandung komponen fenolik seperti kavikol dan eugenol. Seila (2012) Sirih termasuk dalam family Piperaceae, merupakan jenis tumbuhan merambat dan bersandar pada batang pohon lain, yang tingginya 5-15 meter. Sirih memiliki daun tunggal letaknya berseling dengan bentuk bervariasi mulai dari bundar telur lonjong, pangkal berbentuk jantung atau agak bundar berlekuk sedikit, 
ujung daun runcing, pinggir daun rata agak menggulung ke bawah, panjang 5-18 $\mathrm{cm}$. dan berwarna hijau, permukaan atas rata, licin agak mengkilat, tulang daun agak tenggelam,permukaan bawah agak kasar, kusam, tulang daun menonjol, bau aromatiknya khas, rasanya pedas. Seila (2012) Daun sirih hijau mengandung $4,2 \%$ minyak atsiri yang komponen utamanya terdiri dari bethlephenol dan beberapa derivatnya diantaranya Eugeno 26,8$42,5 \%$, Cineol 2,4\%-4,8\%, methyeugenol 4,2-15,8\%, Caryophyllen ( siskueterpen) 3-9,8\%, kavikol 7,2-16,7\%[9]. Dina (2011) Kemudian kerabat dekat dari sirih hijau adalah daun sirih merah (Piper crocatum Rutz\&Pav), kandungan zat kimia dalam daun sirih merah adalah alkaloid, saponin, flavonoid, tannin, minyak atsiri, polifenol, kuinon, dan steroid. Kandungan minyak atsiri yang terdapat didaun sirih merah adalah golongan monoterpen ( $\mathrm{p}$ cymene), golongan seskuterpen ( caryofelen, kadimen estragol), phenylpropane ( hidrosikavicol, eugenol, kavikol, kavibetol), phenol ( karvakrol), allypyrokatekol dan terpena. Senyawa aktif eugenol, kavikol dan karvakrol inilah yang dikenal memiliki aktivitas penghambatan pertumbuhan Candida albicans. Pemanfaatan daun sirih merah dimasyarakat telah dilakukan menurut pengalaman secara turun temurun, senyawa sperti flavonoid, fenolat dan alkaloid diketahui berpotensi sebagai antioksidan. Koes irianto(2012) Mikroba pada umumnya terdapat di mana- mana, termasuk pada tubuh manusia yang dikenal dengan flora normal. Flora normal dapat menimbulkan penyakit apabila masuk ke situs organ atau jaringan lain, serta dapat menimbulkan infeksi yang mungkin timbul setelah terjadinya kerusakan jaringan pada situs-situs yang khusus. Beberapa mikroba sebagai flora normal pada manusia sekaligus sebagai pathogen adalah Candida albicans.

Candida albicans merupakan anggota flora normal selaput lendir, saluran pernafasan, saluran pencernaan, dan genetalia wanita. Candida albicans dapat menimbulkan invasi dalam aliran darah, trombofiebitis, andokaditas atau infeksi pada mata dan organ lain. Jamur ini mempunyai sedikit koloni namun penyebarannnya merata, berwarna putih dan penyebab kandidiasi. Kandidiasi dapat menjangkit selaput lendir, kuku dan 
berbagai organ tubuh. Jamur Candida albican ini merupakan salah satu jenis jamur penyebab keputihan pada vagina wanita, biasanya akan terasa gatal dan keputihan berlebih, berbau tidak sedap sehingga menyebabkan ketidaknyamanan pada bagian genetalia wanita tersebut. Terkait dengan hal itu, masyarakat sudah cukup pintar untuk memanfaatkan obat tradisional sebagai upaya untuk mengurangi dan mencegah tumbuhnya jamur Candida albicans secara berlebih.

Daun sirih merupakan salah satu bentuk ramuan tradisional yang tepat dalam pengobatan ini karena telah diketahui beberapa kandungan yang dimiliki oleh tanaman sirih. Dua varietas sirih yang berbeda yaitu sirih hijau dan sirih merah memiliki kandungan kimia yang berbeda, dan sangat mampu sebagai antifungi maupun sebagai antibakteri.

Menurut Jurnal Kedokteran mengatakan Hasil penelitian sebelumnya bahwa ekstrak daun sirih hijau mampu menghambat pertumbuhan jamur Candida albicans, kandungan zat dari ekstrak daun sirih hijau diduga menjadi faktor yang menghambat pertumbuhan jamur Candida albicans. Ekstrak daun sirih hijau (Piper betle L) juga bisa menghambat bakteri pathogen penyebab pembusukan pada makanan. Hasil penelitian lain juga bahwa daun sirih merah mampu menghambat bakteri Escherichia coli, Staphylococcus aureus, dan Candida albicans dengan konsentrasi tertinggi 50\%. Pada penelitian yang dilakukan oleh Dina Oktaviani (2011) dengan menggunakan daun sirih merah pada jamur Ptyrosporum ovale memberikan efek hambatan pada jamur tersebut.

Pada penelitian ini peneliti ingin menggunakan ekstrak daun sirih hijau (Piper betle L) dan daun sirih merah (Piper crocatum), dengan variasi konsentrasi sebagai variabel bebas dan variabel terikat yaitu Candida albican. Pada penelitian ini juga ekstrak dilakukan dengan cara maserasi atau ekstrak dingin. Dengan cara ini bahan kering hasil gilingan diekstraksi pada suhu kamar secara berturut-turut dengan pelarut yang kepolarannya makin tinggi. Metode ektraksi dingin dengan maserasi adalah proses penyarian simlisia menggunakan pelarut dengan perendaman dan beberapa kali pengocokan atau npengadukan 
pada temperature ruangan (kamar). Cairan penyari akan menembus dinding sel dan dalam rongga sel yang mengandung zat aktif yang akan larut, karena adanya perbedaan konsentrasi lrutan zat aktif didalam sel dan diluar sel maka larutan terpekat didesak keluar. Maka Rumusan Masalah dari penelitian ini sebagai berikut:

1. Apakah ada pengaruh jenis sirih terhadap pertumbuhan jamur Candida albicans?

2. Apakah ada pengaruh variasi konsnetrasi terhadap pertumbuhan jamur Candida albicans?

3. Apakah ada interaksi antara jenis sirirh dan variasi konsentrasi terhadap pertumbuhan jamur Candida albicans?

Mengacu pada rumusan masalah diatas maka tujuan dari penelitian ini adalah:

1. Untuk mengetahui pengaruh jenis sirih terhadap pertumbuhan jamur Candida albicans

2. Untuk mengetahui pengaruh variasi konsentrasi terhadap pertumbuhan jamur Candida albicans

3. Untuk mengetahui interaksi antara jenis sirih dan variasi konsnetrasi terhadap jamur Candida albicans.

\section{METODE PENELITIAN}

Menurut kiemas (2005) Penelitian ini termasuk ke dalam metode penelitian eksperimental, dimana di dalamnya terdapat perlakuan untuk memanipulasi objek penelitian. Desain penelitian yang digunakan pada penelitian ini adalah rancangan acak lengkap (RAL faktorial) dengan 5 perlakuan dan 4 kali ulangan. RAL merupakan rancangan yang paling sederhana. Dalam rancangan ini tidak terdapat lokal kontrol, sehingga sumber keragaman yang diamati hanya dari perlakuan dan galat.

Menurut sugiyono (2010) Penelitian ini menggunakan pendekatan kuantitatif karena data pada penelitian ini berupa angka yang akan dianalisis dengan statistic. Data yang akan diperoleh dari penelitian ini merupakan diameter zona hambat

146 BIOTA: Jurnal Tadris IPA Biologi FITK IAIN Mataram 
pertumbuhan mikroba uji yang diberikan ekstrak daun sirih merah dan daun sirih hijau dengan variasi konsentrasi.

Tabel 1

Rancangan Penelitian

\begin{tabular}{|c|c|c|c|c|c|c|}
\hline \multirow{4}{*}{ Jenis Daun Sirih } & \multirow{5}{*}{ Variabel } & \multicolumn{5}{|c|}{ Konsentrasi \% (B) } \\
\cline { 2 - 7 } & & $\mathbf{1}$ & $\mathbf{2}$ & $\mathbf{3}$ & $\mathbf{4}$ & $\mathbf{5}$ \\
\cline { 2 - 7 } & Sirih Hijau (1) & $\mathrm{A}_{1} \mathrm{~B}_{1}$ & $\mathrm{~A}_{1} \mathrm{~B}_{2}$ & $\mathrm{~A}_{1} \mathrm{~B}_{3}$ & $\mathrm{~A}_{1} \mathrm{~B}_{4}$ & $\mathrm{~A}_{1} \mathrm{~B}_{5}$ \\
\cline { 2 - 7 } & Sirih Merah (2) & $\mathrm{A}_{2} \mathrm{~B}_{1}$ & $\mathrm{~A}_{2} \mathrm{~B}_{2}$ & $\mathrm{~A}_{2} \mathrm{~B}_{3}$ & $\mathrm{~A}_{2} \mathrm{~B}_{4}$ & $\mathrm{~A}_{2} \mathrm{~B}_{5}$ \\
\hline
\end{tabular}

Penelitian ini dilaksanakan di RSUP Mataram, dan waktu pelaksanaan ini yakni pada bulan Agustus 2015.Populasi adalah semua individu atau obyek yang menjadi sumber pengambilan sampel. Populasi yang dijadikan sebagai objek dalam penelitian ini adalah jamur Candida albicans. Sampel merupakan sebagian dari seluruh individu atau obyek yang menjadi obyek penelitian. Sampel dalam penelitian ini adalah biakan murni jamur Candida albicans sesuai standar 0,5 Mc Farland atau sebanding dengan

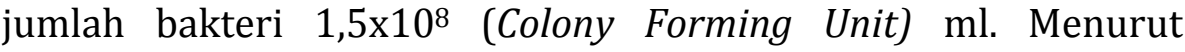
Sugiyono (2010) Instrument penelitian adalah alat atau fasilitas yang digunakan oleh peneliti dalam mengumpulkan data agar pekerjaannya lebih mudah dan hasilnya lebih baik, dalam arti lebih cermat, lengkap dan sistematis sehingga lebih mudah diolah. Menurut sugiyono (2007) Dinyatakan juga bahwa, instrumen penelitian memiliki tujuan untuk mengukur suatu gejala dan jumlah intrumen penelitian tergantung pada variabel yang diteliti. Adapun instrument pada penelitian ini adalah berupa alat dan bahan penelitian. 
Tabel 2

Daftar Alat Penelitian

\begin{tabular}{|c|c|c|c|}
\hline No & Nama Alat & Spesifikasi & Jumlah \\
\hline 1 & 2 & 3 & 4 \\
\hline 1. & Cawan Petri & Diameter $9 \mathrm{~cm}$ & 8 buah \\
\hline 2. & Labu Erlenmeyer & $500 \mathrm{~mL}, 100 \mathrm{~mL}$ & 2 buah \\
\hline 3. & Beaker Glass & $100 \mathrm{~mL}, 500 \mathrm{~mL}$ & 2 buah \\
\hline 4. & Gelas Ukur & $100 \mathrm{~mL}, 10 \mathrm{~mL}, 5 \mathrm{~mL}$ & 1 buah \\
\hline 5. & Corong & - & 2 Buah \\
\hline 6. & Tabung Reaksi & $13 \times 150 \mathrm{~mm}$ & 3 buah \\
\hline 7. & Kaca pengaduk & - & 2 buah \\
\hline 8. & Timbangan ohaus & - & 1 buah \\
\hline 9. & Autoklaf & HL36AE & $1 \mathrm{Buah}$ \\
\hline 10. & Jangka Sorong & - & 1 buah \\
\hline 11. & Blender & PHILIPS & 1 buah \\
\hline 12. & Rak tabung reaksi & - & 1 buah \\
\hline 13. & Jarum inokulasi & - & 2 buah \\
\hline 14. & Pinset & - & 1 buah \\
\hline 15. & Inkubator & Memmert & $1 \mathrm{Buah}$ \\
\hline 16. & Ent-kas/Laminar Air Flow & ESCO & 1 buah \\
\hline 17. & Lampu Bunsen & - & 1 buah \\
\hline 18. & Camera digital & SONY & 1 buah \\
\hline 19. & $\begin{array}{ll}\text { Vaccum } & \text { Rotary } \\
\text { evaporator } & \end{array}$ & EYELA N-N Serieus & 1 buah \\
\hline 20. & Micropipet & - & 2 buah \\
\hline 21. & Lemari es & - & 1 buah \\
\hline 22. & Hot plate & RCH-3 & 1 buah \\
\hline 23. & Blue tip & $8 \mathrm{~mm}$ & $\begin{array}{l}\text { Disesuai } \\
\text { kan }\end{array}$ \\
\hline 24. & Yellow tip & - & $\begin{array}{l}\text { Disesuai } \\
\text { kan }\end{array}$ \\
\hline 25. & Eppendorf tube & - & 6 Buah \\
\hline
\end{tabular}


Adapun bahan-bahan yang digunakan dalam penelitian ini tercantum pada tabel di bawah ini.

Tabel 3

Daftar Bahan Penelitian

\begin{tabular}{|c|l|l|}
\hline No & \multicolumn{1}{|c|}{ Bahan } & \multicolumn{1}{c|}{ Jumlah } \\
\hline $\mathbf{1}$ & \multicolumn{1}{|c|}{$\mathbf{2}$} \\
\hline 1 & Medium MHA & \multicolumn{1}{|c|}{ 2,50 gram } \\
\hline 2 & Aquades & 1 Liter \\
\hline 3 & Biakan Murni jamur Candida albicans & 1 Tabung \\
\hline 4 & Serbuk Daun Sirih Hijau & $300 \mathrm{gr}$ \\
\hline 5 & Serbuk Daun Sirih Merah & $300 \mathrm{gr}$ \\
\hline 6 & Etanol p.a (100\%) & 1,5 L \\
\hline 7 & Antijamur Nistatin (25000 IU) & 1 Tabung \\
\hline 8 & Kertas Saring & 1 Lembar \\
\hline 9 & Kapas & Secukupnya \\
\hline 10 & Tisu & Secukupnya \\
\hline 11 & Aluminium Foil & Secukupnya \\
\hline 12 & Korek Api & 1 Buah \\
\hline 13 & Kertas Label & Secukupnya \\
\hline 14 & NaCl 0.9\% & 10 Ml \\
\hline 15 & Karet & Secukupnya \\
\hline 16 & Kertas Jagung & 3 Lembar \\
\hline 17 & Swab kapas & Secukupnya \\
\hline
\end{tabular}

Pengumpulan data dilakukan dengan mengukur diameter zona hambatan yang terbentuk di sekitar sumuran pada cawan petri berbeda yang telah diberi konsentrasi ekstrak daun sirih hijau dan daun sirih merah pada medium biakan murni jamur Candida albicans. Diameter zona hambatan adalah diameter yang tidak ditumbuhi oleh mikroba di sekitar sumuran. Kusriningrum (2008) Untuk menganalisis data hasil penelitian disajikan dalam bentuk tabel hasil pengamatan, yang dianalisa dengan menggunakan ANOVA (Analysis of Variance) dua arah (two way 
anova) karena ada dua faktor yang mempengaruhi dan dilanjutkan dengan Uji BNT untuk mengetahui seberapa besar pengaruh yang diberikan[6]. Data penelitian ini akan dianalisis secara manual dan dengan SPSS 16,0 for Windows.

\section{HASIL}

Berdasarkan penelitian yang telah dilakukan di Unit Riset Biomedik Prov. NTB dari tanggal 01-23 Agustus 2015 maka didapatkan hasil zona hambat yang ditunjukkan pada Tabel berikut:

Tabel 4

Data Diameter Zona Hambat

\begin{tabular}{|c|c|c|c|c|c|c|c|c|}
\hline \multirow{2}{*}{ Perlakuan } & \multirow{2}{*}{$\begin{array}{l}\text { Ulang } \\
\text { an }\end{array}$} & \multicolumn{6}{|c|}{ Konsentrasi \% } & \multirow{2}{*}{ Total } \\
\hline & & $0 \%$ & $20 \%$ & $40 \%$ & $60 \%$ & $80 \%$ & $100 \%$ & \\
\hline \multirow{4}{*}{$\begin{array}{l}\text { Daun Sirih } \\
\text { Hijau }\end{array}$} & 1 & 0 & 19 & 20 & 22 & 29 & 33 & 123 \\
\hline & 2 & 0 & 17 & 17 & 17 & 19 & 20 & 90 \\
\hline & 3 & 0 & 19 & 20 & 21 & 24 & 35 & 119 \\
\hline & 4 & 0 & 18 & 20 & 21 & 25 & 32 & 116 \\
\hline \multirow{4}{*}{$\begin{array}{l}\text { Daun Sirih } \\
\text { Muda }\end{array}$} & 1 & 0 & 0 & 0 & 0 & 0 & 0 & 0 \\
\hline & 2 & 0 & 0 & 0 & 0 & 0 & 0 & 0 \\
\hline & 3 & 0 & 0 & 0 & 0 & 0 & 0 & 0 \\
\hline & 4 & 0 & 0 & 0 & 0 & 0 & 0 & 0 \\
\hline \multicolumn{2}{|l|}{ Rata-Rata } & 0 & 18,25 & 19,25 & 20,25 & 24,25 & 30 & 112 \\
\hline
\end{tabular}

Tabel di atas menunjukkan bahwa pada penelitian ini zona hambat pada ekstrak daun sirih hijau (Piper betle L) sudah terlihat mulai dari konsentrasi terendah yaitu pada konsentrasi $20 \%$ dengan diameter rata-rata 18,25 $\mathrm{mm}$, dan konsentrasi tertinggi pada konsentrasi $100 \%$ dengan diameter rata-rata $30 \mathrm{~mm}$. Sementara pada ekstrak daun sirih merah (Piper crocatum

150 BIOTA: Jurnal Tadris IPA Biologi FITK IAIN Mataram 
Rutz\&Pav) sama sekali tidak menunjukkan adanya zona hambat baik pada konsentrasi $20 \%$ sampai dengan konsentrasi terbesar $100 \%$. Jadi, dari tabel diatas dapat dilihat adanya perbedaan diameter zona hambat pada ekstrak jenis daun sirih dan peningkatan diameter zona hambat sesuai dengan meningkatnya konsentrasi. Berikut ini grafik rata-rata zona hambat masingmasing ekstrak pada mikroba uji.

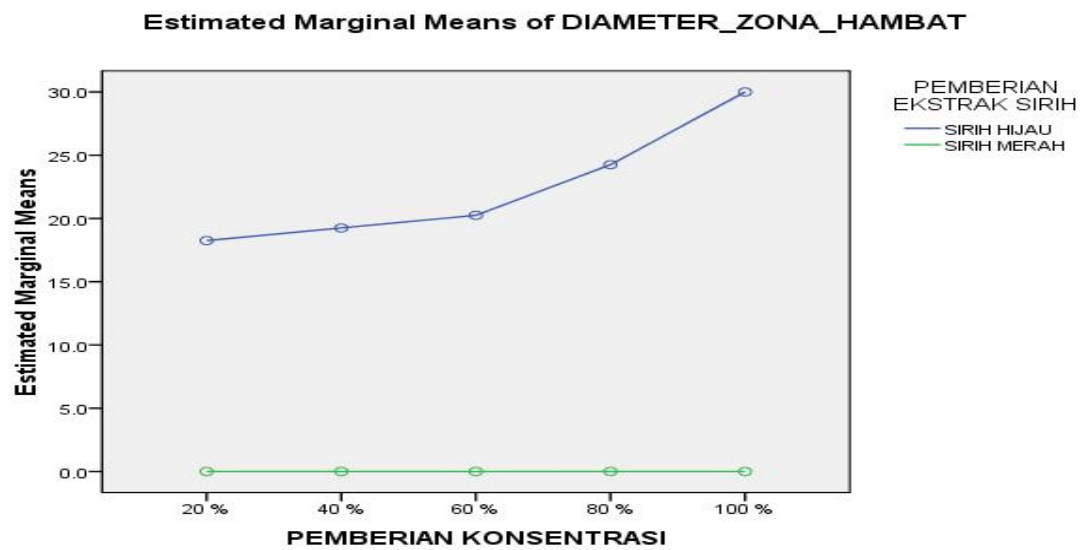

Data pada tabel diatas dianalisis menggunakan Analisis Varians Dua Arah (Two Way Anova), dengan menggunakan SPSS Versi 16. Hasil analisis menunjukkan bahwa $F_{\text {hitung }} A=706,70$ lebih besar dari $F_{\text {tabel }} 5 \%$ pada db $(1 ; 30)=4,17, F_{\text {hitung }} B=6,54$ lebih besar dari $F_{\text {tabel }} 5 \%$ pada db $(4 ; 30)=2,68, F_{\text {hitung }} A B=6,54$ lebih besar dari $F_{\text {tabel }} 5 \%$ pada db $(4 ; 30)=2,68$. Dengan demikian semua $\mathrm{H}_{0}$ ditolak yang berarti terdapat pengaruh yang signifikan jenis daun sirih dan variasi konsentrasi terhadap pertumbuhan jamur Candida albicans serta terdapat interaksi antar faktor A dan faktor B. 
Tabel 5

Hasil Perhitungan ANAVA dengan Menggunakan SPSS Versi 16.

\begin{tabular}{|l|l|l|l|l|l|}
\hline \multicolumn{1}{|c|}{ Source } & $\begin{array}{c}\text { Type III Sum } \\
\text { of Squares }\end{array}$ & Df & $\begin{array}{c}\text { Mean } \\
\text { Square }\end{array}$ & \multicolumn{1}{c|}{ F } & Sig. \\
\hline Corrected Model & $5389.400^{a}$ & 9 & 598.822 & 84.341 & .000 \\
\hline Intercept & 5017.600 & 1 & 5017.600 & 706.704 & .000 \\
\hline PERLAKUAN_A & 5017.600 & 1 & 5017.600 & 706.704 & .000 \\
\hline PERLAKUAN_B & 185.900 & 4 & 46.475 & 6.546 & .001 \\
\hline $\begin{array}{l}\text { PERLAKUAN_A } \\
\text { PERLAKUAN_B }\end{array}$ & 185.900 & 4 & 46.475 & 6.546 & .001 \\
\hline Error & 213.000 & 30 & 7.100 & & \\
\hline Total & 10620.000 & 40 & & & \\
\hline Corrected Total & 5602.400 & 39 & & & \\
\hline
\end{tabular}

Dari tabel diatas menunjukkan bahwa pada factor A terdapat pengaruh yang signifikan perlakuan jenis daun sirih terhadap pertumbuhan jamur Candida albicans. Oleh karena itu, dilakukan uji lanjut dengan uji beda nyata jujur (BNJ) pada taraf signifikasi 5\% dengan tujuan untuk mengetahui perlakuan mana yang lebih berpengaruh terhadap pertumbuhan mikroba uji. Nilai uji BNJ yang didapatkan $=1,97$. Begitu juga dengan factor $\mathrm{B}$ dan $\mathrm{AB}$ masing-masing didapatkan nilai uji $\mathrm{BNJ}=2,38$ dan. Notasi garis yang digunakan untuk menentukan perlakuan mana yang lebih berpengaruh ditunjukkan pada Tabel berikut:

Tabel diatas menunjukkan bahwa huruf latin kecil yang diberikan simbol pada setiap konsentrasi astinya, pada konsentrasi 100\%, dan 80\% mempunyai simbol huruf yang berbeda karena berbeda nyaa ( signifikan) dengan nilai BNJ. Sedangkan pada konsentrasi $60 \%, 40 \%, 20 \%$ mempunyai simbol huruf yang sama karena tidak berbeda nyata dengan nilai BNJ.

152 BIOTA: Jurnal Tadris IPA Biologi FITK IAIN Mataram 


\section{PEMBAHASAN}

Daun sirih hijau dan daun sirih merah sudah dikenal oleh seluruh lapisan masyarakat, khasiatnya sebagai obat tradisional yang paling berpengaruh. Berdasarkan hasil analisis diketahui bahwa jenis daun sirih berpengaruh signifikan terhadap pertumbuhan jamur Candida albicans, oleh karena itu dilanjutkan dengan uji BNJ untuk mengetahui jenis sirih dan konsentrasi yang terbaik. Dari hasil analisis, jenis daun sirih yang terbaik adalah daun sirih hijau, konsnetrasi terbaik untuk menghambat jamur Candida albicans adalah konsentrasi 100 dengan diameter ratarata zona hambat $30 \mathrm{~mm}$.

Menurut Mudatsir Kemampuan ekstrak daun sirih hijau dalam menghambat pertumbuhan jamur disebabkan karena kandungan kimia yang terdapat pada daun sirih hijau fenol, kavikol, kavibetol, flavonoid, saponin, karvakrol, eugenol, dan tannin.kavikol, kavibetol dan karvakrol merupakan turunan dari fenol yang mempunyai daya antibakteri lima kali lipat dari fenol biasa. Fenol mampu menurunkan tegangan permukaan sel dan denaturasi protein. Flavonoid sebagai antiinflamasi. Menurut Pratiwi Tannin merupakan poliferol yang larut dalam air, saponin dapat merusak dinding sel. Fenol merupakan senyawa toksik mengakibatkan struktur tiga dimensi protein terganggu dan terbuka menjadi struktur acak tanpa adanya kerusakan pada struktur kerangka kovalen. Hal ini mengakibatkan protein berubah sifat, aktifitas biologisnya menjadi rusak sehingga protein tidak dapat melakukan fungsinya. Dengan terdenaturasinya protein sel maka semua aktivitas metabolism sel dikatalisis oleh enzim sehingga mikroba atau jamur tidak dapat bertahan hidup. Tannin mengahambat kerja enzim ekstraseluler mikroba dan jamur, dan bekerja langsung pada metabolism dengan cara menghambat fosforilasi oksidasi. Saponin berikatan dengan kompleks polisakarida pada dinding sel, sehingga dapat merusak dinding sel. Dengan demikian pada penelitian ini kandungan kimia pada daun sirih hijau terbukti. Sedangkan ekstrak daun sirih merah terhadap Candida albicans tidak memberikan hambatan. Hal ini diduga karena pelarut aquades yang digunakan untuk melarutkan ekstrak membentuk suspense 
sehingga jika dibiarkan dalam waktu yang lama akan terbentuk endapan. Aquades berdifusi terlebih dahulu kedalam agar, ekstrak daun sirih merah kemungkinan bisa berdifusi tapi membutuhkan waktu yang lebh lama dari pada waktu inkubasi. Padahal pada beberapa jurnal dan literature bahwa sirih merah memiliki kandungan kimia yang bersifat antifungi dan mampu menghambat Candida albicans meski dengan diameter zona hambat yang tidak terlalu besar akan tetapi pada penelitian ini tidak terbukti. Hal ini mungkin juga disebabkan proses maserasi yang idak lama dan hanya satun kali penyaringan. Secara umum bahan herbal dengan komponen aktifnya dalam menhambat aktivitas mikroba melalui beberapa mekanisme anatara lain mengganggu senyawa penyusun dinding sel, meningkatkan permeabilitas membrane sel, menginaktifasi enzim metabolic dan merusak fungsi bahan genetic. Menurut Pelezar (2008)Senyawa antimikroba tersebut dapat melekat atau berdifusi ke dalam sel menyebabakan perubahan berupa kerusakan ataupun kematian dari sel mikroba tersebut. Akan tetapi keefektifan senyawa antimikroba dipengaruhi juga oleh senyawa antimikroba, jenis mikroba dan besarnya konsnetrasi senyawa yang digunakan.

\section{PENUTUP}

\section{Simpulan}

Berdasarkan hasil analisis data dan pembahasan, dapat disimpulkan bahwa:

1. Ada pengaruh yang signifikan untuk perbedaan jenis daun sirih dalam menghambat jamur Candida albicans, karena $\mathrm{F}_{\text {hitung }(706,70)} \geq \mathrm{F}_{\text {tabel }(4,17)}$ artinya menolak $\mathrm{H}_{0}$.

2. Ada pengaruh variasi konsentrasi ekstrak terhadap jamur Candida albicans, karena $F_{\text {hitung(6,54) }} \geq F_{\text {tabel(2,68) }}$ artinya menolak $\mathrm{H}_{0}$

3. Ada interaksi antara jenis daun sirih dan variasi konsentrasi ekstrak, karena $\mathrm{F}_{\text {hitung }}(6,54) \mathrm{AB} \geq \mathrm{F}_{\text {tabel }}(2,68)$ artinya menolak $\mathrm{H}_{0}$. 


\section{Saran}

1. Bagi para peneliti baik mahasiswa atau pihak lain yang terkait diharapkan dapat melakukan penelitian lanjutan dengan pelarut ekstrak yang berbeda atau dengan metode lain.

2. Sosialisai Daun Sirih Hijau sebagai obat masalah keputihan. Sirih Hijau tidak hanya mampu mengatasi masalah keputihan tetapi juga mampu mengatasi beberapa msalah kesehatan lainnya.

\section{DAFTAR PUSTAKA}

Dina Oktaviani. Uji Banding Efektivitas Ekstrak Daun Sirih Merah Dengan Zinc Pyrithione 1 \% Terhadap Pertumbuhan Pityrisporum ovale Pada Penderita Berketombe. Program Penidikan Sarjana Kedokteran Fakultas Kedokteran Universitas Diponegoro. 2012.

Galuh Martin Maytasari "Perebdaan Efek Antifungi Minyak atsiri Daun Sirih Hijau, Daun Sirih Merah dan Resik V Terhadap Pertumbuhan Jamur Candida albicansi "Skripsi Fakultas Kedokteran Universitas Sebelas Maret Surakarta. 2010.

Jurnal Kedokteran Syiah Kuala Volume 7 Nomor 3 Desember.2007.

Kemas Ali Hanafiah, Rancangan Percobaan Teori dan Aplikasi, Jakarta: Raja Grafindo Persada, 2005.

Koes Irianto. Menguak Dunia Mikroorganisme jilid 1, Bandung: Yrama Widya.. 2012.

Kusriningrum, Perancangan Percobaan, Surabaya: Airlangga University Press, 2008.

Pratiwi Mahardika Putri "Hasil Ekstraksi Daun Sirih Hijau (Piper bettle L) Sebagai Pengawet Alami Pada Bakso Sapi“(Jurnal Peneltian Jurusan Teknologi Industri Pertanian Universitas Brawijaya Malang.

Pelezar dan Chand. Dasar-dasar Mikrobiologi. Jakarta: UI Press. 2008

Seila Inayatullah" Efek Ekstrak Daun Siirh Hijau (Piper betle L) Terhadap Pertumbuhan Bakteri Staphylococcus aureus". ( 
DIANA ETIKA RAHMA UTAMI, DKK.

Laporan Penelitian Program Studi Pendidikan Dokter Fak. Kedokteran dan Ilmu Kesehatan Univ. Islam Negeri Syarif Hidayatullah Jakarta. 2012. H,5

Sugiyono, Metode Penelitian Pendidikan Pendekatan Kuantitatif, Kualitataif dan R\&D, Bandung: Alfabeta, 2010.

Sugiyono, Metode Penelitian Kuantitatif kualitatif dan R\&D Bandung: Alfabeta, 2007.

156 BIOTA: Jurnal Tadris IPA Biologi FITK IAIN Mataram 